\title{
Influence of organic growing media in combination with microbial bio- agents (Clonotri or Sublic) on the growth parameters of olive (Olea europaea L.) plantlets in the nursery
}

\author{
Ismail A.M ${ }^{1}$, D'Onghia A.M ${ }^{2}$, and Nigro $F^{3}$ \\ ${ }^{1}$ Plant Pathology Research Institute, Agriculture Research Center, Giza, Egypt, \\ e-mail:ahmedm244@yahoo.com ${ }^{2}$ Mediterranean Agronomic Institute, Bari, Italy \\ ${ }^{3}$ Department of plant protection and microbiological application, \\ University of Bari, Italy
}

\begin{abstract}
Composting and the use of compost products in horticulture and agriculture have been researched widely. In this study three growing media were investigated. Growing media were treated or not with either fungal commercial formula "Clonotri" based on (Trichoderma harzianum Fv178, Clonostachys rosea Fv114) or bacterial commercial formula "Sublic" based on (Bacillus licheniformis and $B$. subtilis). The effects of the different growing media (organic MAIB, organic MAIB-ECOS, conventional MAIB), alone or in combination with biocontrol agents (Clonotri or Sublic), on vegetative parameters (plant height, plant weight and root weight) of olive plantlets (CV, Leccino) inoculated or not with Verticillium dahlia, were evaluated. Olive plantlets grown in the un-inoculated media showed a significant increase in all vegetative parameters. The two organic growing media increased significantly all vegetative parameters, in which the higher effect was obtained using the organic MAIBECOS in combination with the two microbial bio-agents.
\end{abstract}

\section{INTRODUCTION}

Key words: growing media, bio-products, olive

In addition to their well-known use for soil amendment, an increasingly popular use of composts is a constituent in container media. The two main reasons of this popularity are: I) in many cases non-edible crops such as ornamentals, forest, garden trees and shrubs etc. can serve as a safe outlet for composts that may be considered as non-desirable for food crop production, II) various composts act equally well as peat moss in growing media, while their cost is considerably lower. The fact that mature composts are also suppressive to several soil-borne pathogens, of which peat is conducive and has encouraged many growers to substitute part or all of the peat with such composts. Typical examples for the use of composts in container media include transplant production, substrates for pot plants, forest and fruit tree saplings and substrates for greenhouse-grown plants, especially ornamentals but in some cases also edible crops. (Raviv, 2008).
Antagonistic micro-organisms such as fungi and bacteria have been used widely to control several plant pathogens, and they are promising bio-agents for the improvement of plant production (Postma et al., 2000; Schmilewski, 2004). Some of their properties, such as the production of enzymes could be the reason for better plant growth (Gruda et al., 2004). Böhme et al., (2005) and Juhlke et al., (2005) reported that better plant growth due to the addition of micro-organisms could sometimes be obtained in soilless culture and in container plant production. The possibility to assess, measure and modulate microbial activity could represent a possible strategy to improve the usefulness of such growing media (Handreck, 1992; Gagnon and Simard, 1999). However, selection of the proper media components is critical to the successful production of plants. Therefore, the aim of our study was to evaluate three types of organic growing media amended or not with two microbial bio-agents. 


\section{MATERIALS AND METHODS}

The experiment was carried out on 18-months old cv Leccino olive plants, which were either self-rooted or grafted onto $O$. oleaster rootstock. The plants were grown in 3 types of organic MAIB media ('Organic MAIB-BIO' and 'Organic MAIB-ECOS') and in the MAIB conventional medium (Table.1). Two commercial formula of bio-fungicides Clonotri (ELEP s.a.s Milan, Italy), based on (Clonostachys rosea Fv114 and Trichoderma harzianum Fv178) and Sublic, based on (Bacillus. licheniformis and B. subtilis) were used in this study. The two organic MAIB growing media were characterized by the presence of two components which were used separately or in combination. They were: Guanito (Italpollina, Verona-Italy), which is a bio-fertilizer obtained from poultry manure and registered for organic agriculture.ECOS, which is certified organic commercial compost (BERCO Company) and has an acceptable level of heavy metals. It is obtained from composting different organic fractions coming from the maintenance of green ornamental residues.

The two bio-agents, Clonotri and Sublic, were drenched to the soil (7-days before transplanting) using the recommended concentration written on the label.
Verticillium dahliae inoculum was prepared as a conidial suspension $\left(4 \times 10^{6} \mathrm{CFU} / \mathrm{ml}\right)$ from a mix of isolates non-defoliating pathotypes (V28, V105, V147, and V110) which were provided by the collection of the Dipartimento di Protezione delle Piante e Microbiologia Applicata (DPPMA), University of Bari-Italy. Isolates were grown on potato dextrose agar (PDA) in Petri dishes for 4 days at $27{ }^{\circ} \mathrm{C}$. The seedlings were inoculated by dipping the roots in the conidial suspension for $10 \mathrm{~min}$. Plants immersed for $10 \mathrm{~min}$ in the water were used as uninoculated control. After transplanting, plants were again drenched with a suspension of Clonotri or Sublic, according to the treatments.

Plant heights were recorded at monthly interval. Pruning of the lateral shoots was practiced to enhance vertical growth of the plant. After 15 months of the experiment, plants were uprooted, washed under running tap water. The entire plant and the fresh roots were separately weighted.

Trials were arranged in a completely randomized factorial design. In this experiment there were 10 replications per treatment and two factors were considered as source of variation:

Table 1: The components of conventional MAIB- soil mixtures and organic growing media

\begin{tabular}{|c|c|c|c|c|c|}
\hline Organic MAIB-ECOS & $\%$ & Organic MAIB-BIO & $\%$ & Conventional MAIB & $\%$ \\
\hline Sand & 20 & Sand & 20 & Sand & 20 \\
\hline Perlite & 15 & Perlite & 15 & Perlite & 15 \\
\hline Pomice & 20 & Pomice & 20 & Pomice & 20 \\
\hline Peat moss & 15 & \multirow{3}{*}{ Peat moss } & \multirow{3}{*}{45} & \multirow{3}{*}{ Peat moss } & \\
\hline ECOS (Compost) & 30 & & & & 45 \\
\hline sulfur & 0.16 & & & & \\
\hline \multirow{2}{*}{ Guanito } & \multirow{2}{*}{1} & \multirow{2}{*}{ Guanito } & \multirow{2}{*}{1} & *Nitrofosca blue & 0.075 \\
\hline & & & & *Osmocote & 0.075 \\
\hline Microelements & 0.02 & Microelements & 0.02 & Microelements & 0.02 \\
\hline
\end{tabular}

*Slow release fertilizers contain micronutrients. 
1) Growing media (Conventional MAIB, Organic MAIB and Organic MAIB ECOS);

2) Bio-control agents (Clonotri, Sublic and untreated plantlets).

The main effects of these factors on the plant growth, as well as their combined effects, were determined. Data were submitted to the analysis of variance and the mean values of the main effects, as well as their interaction, were compared by using the Duncan Multiple range test $(P<0.05)$ (Statistical analysis 7 Software).

\section{RESULTS}

The main effect of growing media and Biocontrol agents

Un-inoculated olive plantlets (i.e. without $V$. dahliae) growing on Organic MAIB-BIO and Organic MAIB-ECOS media showed a significantly higher plant height than those grown in the Conventional MAIB substrate (Table.2). In the case of inoculated olive plantlets, Organic MAIB-BIO growing media significantly increased plant height, as compared to the other growing media tested (Table.3). In addition, Treating with Clonotri increased plant height, with values significantly different from plants treated with Sublic or untreated control, in both inoculated and uninoculated plants (Table 2, 3), while Sublic was able to increase, significantly, plant height only in inoculated plants (Table.3).

Table.2 The main effect of growing media and biocontrol agents, as well as their interaction on growth parameters of olive plantlets Un-inoculated with $V$. dahliae.

\begin{tabular}{|c|c|c|c|c|}
\hline \multicolumn{5}{|c|}{$F$ values } \\
\hline Factors & $\begin{array}{l}\text { Degrees } \\
\text { of } \\
\text { freedom }\end{array}$ & $\begin{array}{l}\text { Plant } \\
\text { height }\end{array}$ & $\begin{array}{l}\text { Plant } \\
\text { weight }\end{array}$ & $\begin{array}{l}\text { Root } \\
\text { weight }\end{array}$ \\
\hline $\begin{array}{l}\text { Growing } \\
\text { media }(\mathrm{A})\end{array}$ & 2 & $3.56^{*}$ & $15.49^{\star \star *}$ & $41.13^{* \star *}$ \\
\hline $\begin{array}{l}\text { Bio-control } \\
\text { agents (B) }\end{array}$ & 2 & $15.47^{* * *}$ & $5.46^{* *}$ & $14.57^{* \star *}$ \\
\hline $\begin{array}{l}\text { Interaction } \\
(\mathrm{A} \times \mathrm{B})\end{array}$ & 4 & $2.83^{*}$ & $5.72^{\star \star \star}$ & $7.61^{* * *}$ \\
\hline
\end{tabular}

The $F$ value for the main effects and for the interaction is statistically significant for $P \leq 0.05\left(^{*}\right)$, $P \leq 0.01{ }^{(*)}$ ), and $P \leq 0.001{ }^{(* \star)}$.
Olive plantlets inoculated with $V$. dahliae grown in Organic MAIB-BIO and Organic MAIB-ECOS showed a significant increase of plant weight as compared to the Conventional MAIB growing media (Table.3), the effect of Organic MAIBECOS in increasing plant weight was more evident in uninoculated plants followed by Organic MAIB-BIO with values significantly different from each other and from the Conventional MAIB growing media (Table.2). Moreover, root weight of plants grown in Organic MAIB-ECOS inoculated or not with $V$. dahliae was significantly different from plants grown in Organic MAIB-BIO and Conventional MAIB growing media (Table. 2, 3).

Table .3 The main effect of growing media and biocontrol agents as well as their interaction on growth parameters of olive plantlets Inoculated with $V$. dahliae.

\begin{tabular}{lllll}
\hline \multicolumn{5}{c}{ F values } \\
\cline { 1 - 4 } Factors & $\begin{array}{l}\text { Degrees } \\
\text { of } \\
\text { Freedom }\end{array}$ & $\begin{array}{l}\text { Plant } \\
\text { height }\end{array}$ & $\begin{array}{l}\text { Plant } \\
\text { weight }\end{array}$ & $\begin{array}{l}\text { Root } \\
\text { weight }\end{array}$ \\
\cline { 1 - 2 } $\begin{array}{l}\text { Growing } \\
\text { media (A) }\end{array}$ & 2 & $7.06^{* *}$ & $6.06^{* *}$ & $8.95^{* *}$ \\
\cline { 1 - 1 } $\begin{array}{l}\text { Biocontrol } \\
\text { a gents (B) }\end{array}$ & 2 & $37.53^{* * * *}$ & $12.67^{* * *}$ & $41.43^{* * * *}$ \\
\cline { 1 - 1 } $\begin{array}{l}\text { Interaction } \\
\text { AxB }\end{array}$ & 4 & 1.01 & 1.10 & $4.06^{* *}$ \\
\hline
\end{tabular}

The $F$ value for the main effects and for the interaction is statistically significant for $P \leq 0.05\left(^{*}\right)$, $P \leq 0.01\left(^{* *}\right)$, and $\left.P \leq 0.001{ }^{(* *}\right)$.

\section{The effect of combination between growing media and bio-control agents}

Treating with Clonotri increased the plant height of the plantlets in all growing media, with values significantly higher than the untreated control. Similar results were obtained for plants both uninoculated and inoculated with $V$. dahliae. The combination of Clonotri with organic media was the best for improving the plant height (Fig. $1 \mathrm{~A}$ and $\mathrm{B}$ ).

Olive plantlets un-inoculated with $V$. dahliae and grown in Organic MAIB-ECOS amended with Clonotri showed significantly higher plant and root weight values (Fig. $2 \mathrm{~A}$ and $\mathrm{C}$ ) as compared 7 to the other combinations; intermediate values 
(A)

$$
\begin{aligned}
& \text { Uninoculated with } V \text {. dahliae } \\
& \text { Growing m edia*Bi o-products; LS Means } \\
& \text { Current eff ect: } \mathrm{F}(4,567)=2.8300, \mathrm{p}=.02412 \\
& \\
& - \text { Conventional MAIB } \\
& - \text { Organic MAIB } \\
&
\end{aligned}
$$

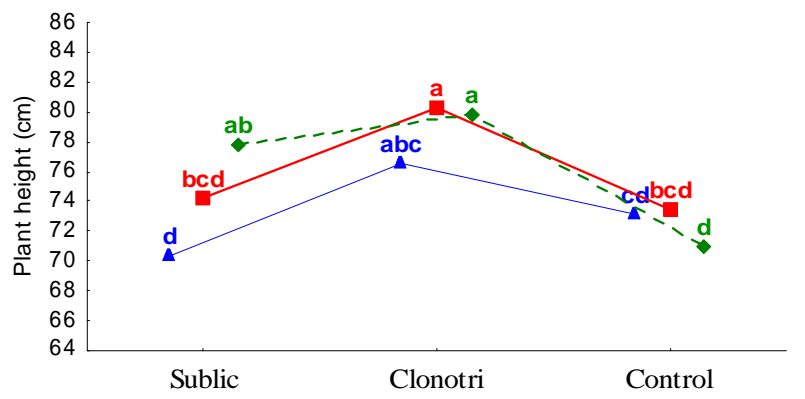

(B)

Inoculated with V. dahliae

Growing media*Bio-products; LS Means Current effect: $F(4,567)=1.0136, p=.39969$ $\rightarrow$ Conventional MAIB $\rightarrow$ Organic MAIB

$\rightarrow$ Organic MAIB ECOS

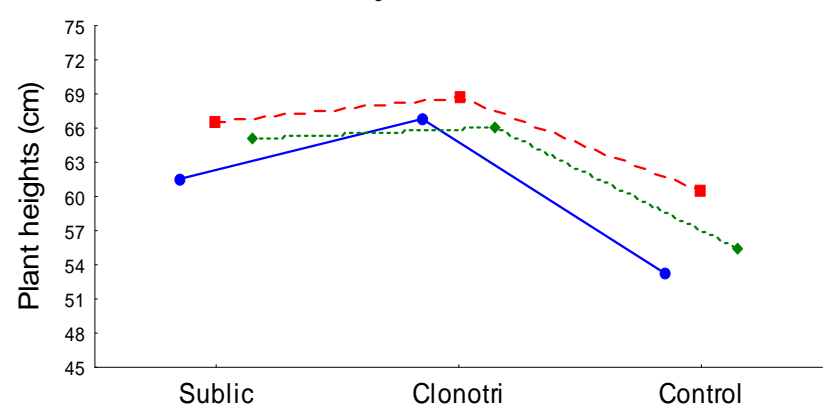

Fig .1 Combined effect of the bio-agents (Sublic or Clonotri) and growing medium (Conventional MAIB, Organic MAIB BIO, and Organic MAIB ECOS) on plant height of olive plantlets, cV Leccino, grafted onto O. oleaster. The effect was tested either on un-inoculated plantlets (A) or on plantlets inoculated with $V$. dahiae (B). Data were collected 15 months after the start of the trials. Mean separation according to Duncan's multiple range test $(P \leq 0.05)$.
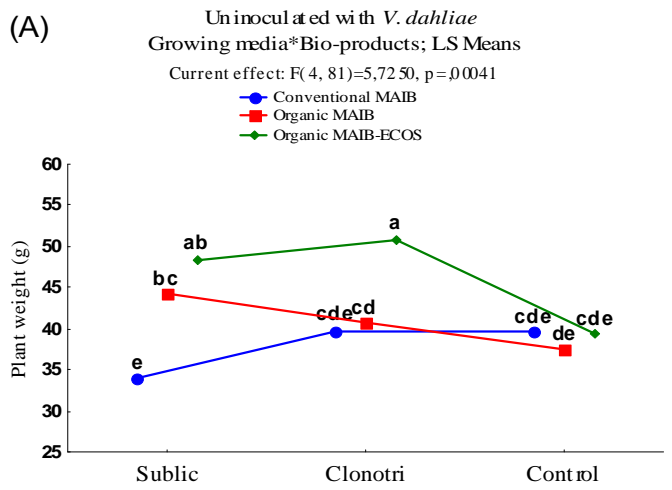

(C)

Uni noal ated with $V$. dahl iae Growing media*Bio-products; LS Means Current effect: $F(4,81)=7,6134, p=, 00003$ $\rightarrow$ Conventional M

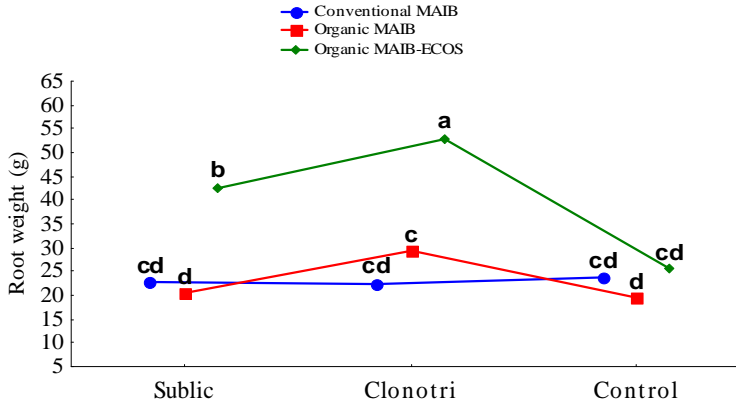

Inoculated with V. dahliae Growing media*Bio-products; LS Means Current effect: $F(4,81)=1,1009, p=, 36188$ $\rightarrow$ Conventional MAIB $\rightarrow$ - Organic MAIB

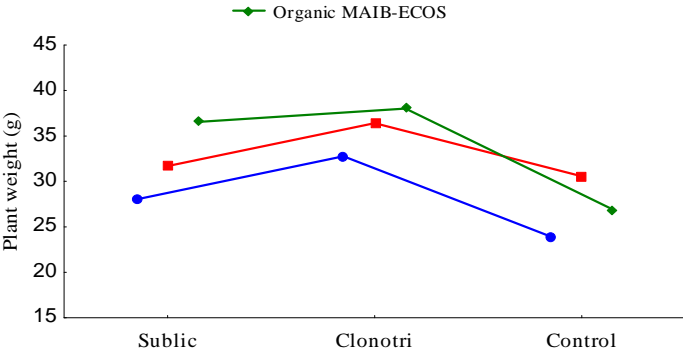

(D) Inoalat ed with V. dahliae Ino allat ed with $V$. dahliae
Growing media*Bio-products; LS Means
Current effect: $\mathrm{F}(4,81)=4,0694, \mathrm{p}=, 00468$
$\rightarrow$ Conventional MAIB
$\rightarrow$ Organic MABB
$\rightarrow$ Organic MAIB-ECOS

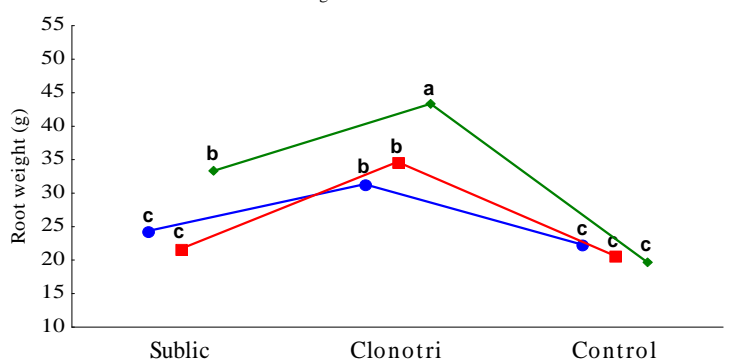

Fig. 2 Combined effect of bio-agents (Clonotri and Sublic) and growing media (Conventional MAIB, Organic MAIB BIO, and Organic MAIB-ECOS) on plant weight and root weight of olive plantlets (cv. Leccino), grafted onto O. oleaster. The effect was tested either on un-inoculated plantlets $(A$ and $C$ ) or on plantlets inoculated with $V$. dahiae $(B$ and $D)$. Data were collected 15 months after the start of the trials. Mean separation according to Duncan's multiple range test $(P \leq 0.05)$. 
were obtained from plants grown in organic media amended with Sublic. Similar results were obtained for plants inoculated with $V$. dahliae (Fig. 2 B and D). In fact, Clonotri increased plant and root weight as compared to untreated control. Therefore, the combination between Clonotri and Organic MAIB-ECOS gave root weight values significantly higher than the other combinations (Fig. 2D).

\section{DISCUSSION}

Composting and the use of compost products in horticulture and agriculture have been researched widely (Marfá et al., 2002). Different substrates have several materials, which could affect direct and indirect on plant growth and plant development (Peyvast et al., 2008). In our study plants were showed a significant development in growth parameters in growing media Organic MAIB-ECOS and Organic MAIB$\mathrm{BIO}$ than in the Conventional MAIB. In addition, growth parameters showed an increasing tendency in growing media Organic MAIBECOS < Organic MAIB-BIO < Conventional MAIB, being the first two growing media not significantly different but different from the third one. Thus, these growing media suggested acceptable physical-chemical properties that were probably suitable for olive plants growth. As Organic MAIB-ECOS had a higher (EC) value, this property reflected the availability of nutrients and subsequently increasing plant uptake of these nutrients, therefore our findings were similar to those obtained by Sonneveld and Voogt, (2008), who have found that the lowest uptake concentration for Kohlrabi and Lettuce plants at the lowest EC value. All the growing media showed $\mathrm{pH}$ values from 6.6 to 6.9 , so that; the availability of either macro or microelements was high in this level, because the $\mathrm{pH}$ constitutes a significant limiting factor particularly in nursery production system. Guanito organic product derived from poultry manure, so that the manure is also improving the plant resistance against soil-borne pathogens.

According to Nakkeeran et al., (2002), the microbial antagonists act through antibiosis, secretion of volatile toxic metabolites, mycolytic enzyme production, parasitism and competition for space and nutrition. Some of these properties, such as the production of enzymes could be the reason for better plant growth (Gruda et al., 2004). Our results indicated that, the treatment with the (Clonotri) antagonistic product, based on two fungi $T$. harizanum Fv178 and $C$. rosea Fv114, had a great effect on improving olive plant growth parameters such as, plant height, plant weight and root weight either with inoculated or un-inoculated plants with V. dahliae. Böhme et al., (2005) reported that better plant growth, due to the addition of microorganisms, could be sometimes obtained in soil-less culture and in container plant production. Therefore, prophylactic application of beneficial microorganisms, even in the absence of a plant pathogen, may increase plant growth. In addition, Hanson (2000) found that some strains of $T$. virens have a growthpromoting effect on cotton but this effect has not been demonstrated. As we have observed over the time, the effect of the Clonotri on the growth of olive plantlets appeared after 4 months from the beginning of the treatments. Thus, the growth promotion does not appear early in the growth of the plants and is not as pronounced as growth promotion reported on other crops caused by other Trichoderma species (Harman, 2000).

\section{CONCLUSION}

It was evident from our results that the physical and chemical properties as well as the components (organic amendments) of Organic growing media enabled to maintain high growth of olive plantlets grafted onto Oleaster rootstock. Furthermore, Clonotri and Sublic bio-agents were able to increase all vegetative parameters (i.e. plant growth and height) either inoculated or not with Verticillium dahliea.

\section{REFERENCES}

Boehme, M., Schevtschenko, J. and Pinker I. (2005). Effect of biostimulator on growth of vegetables in hydroponical systems. Acta Horticulture, 697:337-344.

Gagnon, B. and Simard, R.R. (1999). Nitrogen and phosphorous release from on-farm and industrial composts. Canadian Journal of Soil Sciences. 79:481-489. 
Gruda, N., Maher, M.J. and Prasad, M. (2004). The effect of microbial additives in growing media on plant growth. Teagasc Research Report Kinsealy Research Centre, Dublin, Ireland.

Handreck, K.A. (1992). Rabid assessment of the rate of nitrogen immobilization in organic components of potting media: II Nitrogen drawdown index and plant growth. Comm. Soil.Sci. Plant. Anal. 23:217230.

Hanson, E.L (2000). Reduction of Verticillium Wilt Symptoms in Cotton Following Seed Treatment with Trichoderma virens. The Journal of Cotton Science, 4:224-231.

Harman, G.E. (2000). Myths and dogmas of biocontrol: Changes in perceptions derived from research on Trichoderma harzianum T-22. Plant Disease, 84:377-393.

http://zope2.agrar.huberlin.de/struktur/institute/gbw/str uktur/gpfls/gb/pub htm.

Juhlke, S., Gruda, N., Maher, M. and Prasad, M. (2005). The effect of microbial additives to growing media on plant growth, yield and quality parameters under salt stress conditions. BGHLSchriftenreihe, Tagungsband. 24, S.49.

Marfá, O., Lemaire, F., Cáceres, R., Giuffrida, F. and Guérin, V. (2002). Relationships between growing media fertility percolate composition and fertigation strategy in peat-substitute substrates used for growing ornamental shrubs. Scientia Horticulture, 94:309-321.
Nakkeeran, S., Krishnamoorthy, A. S., Ramamoorthy, V. and Renukadevi, P. (2002). Microbial inoculants in plant disease control. Journal of Ecobiology, 14:83-94.

Peyvast, G.h., Noorizadeh, M., Hamidoghli, J. and Ramezani-Kharazi, P. (2008). Effect of four different substrates on growth, yield and some fruit quality parameters of cucumber in bag culture. Acta Horticulture, 779:535-540.

Postma, J., Willemsen-deKlein, M.J.E.I.M. and Van Elsas, J.D. (2000). Effect of the indigenous microflora on the development of root and ceown rot caused by Phythium aphanidermatum in cucumber grown on rock wool. Phytopathology, 90(2):125-133.

Raviv, M. (2008). The Use of Compost in Growing Media as Suppressive Agent against Soil-Borne Diseases. Acta Horticulture, 779:39-49.

Schmilewski, G. (2004). Efforts at biocontrol of Fusarium oxysporium f.sp.cyclaminis in peat media. Acta Horticulture. 644:511-516.

Sonneveld, C. and Voogt, W. (2008). Nutrient concentrations of plant tissues of greenhouse crops as affected by the EC of the external nutrient solution. Acta Horticulture, 779:313-320. 